\title{
The Impact of State Lotteries and Casinos on State Bankruptcy Filings
}

\author{
By \\ Kent Grote and Victor Matheson
}

February 2013

\section{COLLEGE OF THE HOLY CROSS, DEPARTMENT OF ECONOMICS \\ FACULTY RESEARCH SERIES, PAPER NO. 13-02*}

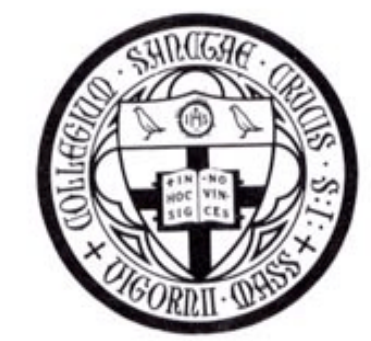

Department of Economics

College of the Holy Cross

Box 45A

Worcester, Massachusetts 01610

(508) 793-3362 (phone)

(508) 793-3708 (fax)

http://www.holycross.edu/departments/economics/website

*All papers in the Holy Cross Working Paper Series should be considered draft versions subject to future revision. Comments and suggestions are welcome. 


\title{
The Impact of State Lotteries and Casinos on State Bankruptcy Filings
}

\author{
By \\ Kent Grote $^{\dagger}$ \\ College of the Holy Cross \\ and \\ Victor Matheson ${ }^{\dagger \dagger}$ \\ College of the Holy Cross
}

February 2013

\begin{abstract}
Over the past half century, there has been an increasing prevalence of legalized gambling in the US. At the same time there is a general recognition, empirically supported in the economics literature, that spending on lottery and gaming products tends to be regressive in nature. In addition, gambling addiction is a widely acknowledged social problem. This raises the question of whether the increased presence of casinos and state lotteries results in relatively more bankruptcy filings in the states that offer them. This paper adds to the existing literature by comparing the relative impact of the presence of lotteries to that of casinos on both personal and business bankruptcies. States that adopted lotteries and casinos prior to 1995 experienced significantly higher personal bankruptcy rates while the effect of lottery and casino adoption on personal bankruptcies has disappeared since that time.
\end{abstract}

JEL Classification Codes: K35, H71, L83

Keywords: lotto, lottery, public finance, gambling

We are grateful for the excellent research assistance of Chris Kalpin.

${ }^{\dagger}$ Department of Economics and Business, Lake Forest College, Lake Forest, IL 60045, 847-735-5196 (phone), 847-735-6193 (fax), grote@lfc.edu

${ }^{\dagger}$ Department of Economics, Box 157A, College of the Holy Cross, Worcester, MA 01610-2395, 508-793-2649 (phone), 508-793-3710 (fax), vmatheso@holycross.edu 


\section{Introduction}

US bankruptcy laws allow for individuals and businesses to file for bankruptcy in order to pay off or restructure outstanding debt that cannot be paid. Recent contributions to the gambling literature have addressed the question of whether gambling, and particularly the increased presence of casinos in the United States, has contributed to personal bankruptcy filings. This paper adds to the existing literature by examining data over a longer timeframe, 1983-2010, potentially capturing longer run effects of legalized gaming than previous studies. In addition, we examine both business and personal bankruptcies. Business bankruptcies should be driven primarily by overall economic trends while personal bankruptcies may also reflect changes in personal spending decisions potentially driven by access to gambling products. Finally, most previous studies have focused exclusively on the impact of casinos on bankruptcy rates while this paper also addresses the effect of state lotteries. Overall, we find that legalized gambling appears to have no significant effect on business bankruptcies while the adoption of both state lotteries and casinos was associated with a statistically significant increase in personal bankruptcies during the 80 s and early 90 s but this association disappears in later years.

Modern state lotteries have existed in the United States since 1964, with many states adding lotteries in the 1980s and 1990s as state fiscal problems evolved and lottery sales offered the ability to increase revenues to the state without increasing other forms of taxation. There are currently lotteries offered in 43 states and the District of Columbia. The modern era of casino gaming in the United State began in Nevada in 1931 while Atlantic City, New Jersey followed in 1976. Over the next two decades, gambling spread throughout the country, and by the end of 2010, there were 15 states that offered commercial land-based or riverboat casinos in their jurisdictions and 28 states that had Native American casinos. 
Much of the growth in lotteries began in the late 1970s and into the 1980s and 1990s, while casino growth primarily occurred in the late 1980s and into the 1990s. Coincidentally, this also happens to be a time period where bankruptcy filings, both by individuals and by businesses were growing as well. This paper will attempt to isolate the relative impacts of lottery growth and casino growth on bankruptcy filings to determine if these gambling activities have contributed significantly to the increase in bankruptcy filings.

\section{Literature Review}

\section{A. Bankruptcies and Gambling}

The existing literature on the relationship between gambling activities and bankruptcy filings does not find a consistent pattern. On the one hand, using state-level data from 1962 to 1998 for Nevada, New Jersey and Mississippi, the US Treasury (1999) finds no significant relationship between casino activity and bankruptcy filings in those states. The National Opinion Research Center (NORC) considers 100 communities, 45 of which had a casino within a 50-mile radius, and finds that the presence of a nearby casino did not have a significant impact on bankruptcy filings. Similarly, de la Vina and Bernstein (2002) also consider if there is a significant relationship between bankruptcy filing rates and the presence of a casino within 50 miles of a community. Using county level data from 1989 to 1994, they also conclude that there is no significant relationship between bankruptcy rates and the presence of a nearby casino or pari-mutuel wagering facility. Thalheimer and Ali (2004) find similar results to de la Vina and Bernstein in their study of both casinos and pari-mutuel racetrack casino facilities for 398 counties in Illinois, Iowa, Missouri, and Mississippi from 1990 through 1997. 
Other studies, however, do find a statistically significant relationship between casinos and bankruptcies. Nichols, Stitt and Giacopassi (2000) compare paired counties in the same states as Thalheimer and Ali (2004) and do find that casino openings are associated with increased bankruptcy filings in five of the eight paired counties examined from 1989 to 1998. Barron, Staten and Wilshusen (2002) undertake a broader study of over 3,000 counties nationwide from 1993 to 1999 and, while they find that the presence of casinos is correlated with higher bankruptcy filings, they find this effect to be very small, and the combined impact of a stagnant economy and rising consumer debt had a far greater impact than the presence of casinos in explaining bankruptcy filings over that time period.

Boardman and Perry (2007) find that the presence of horse tracks in Kentucky between 1989 and 2001 has a significant impact on personal bankruptcy filings while the presence of casinos does not. For the 20 counties studied, they find counties within 28 miles of a horse racing track experienced 9.25\% higher bankruptcy filing rates than other counties. Goss, Morse and Deskins (2009) find a statistically significant relationship between casinos and bankruptcy filings using county level panel data from 1990 to 2005. In their study, they also consider the length of time that a casino is in operation and find evidence that the continuing presence of a casino in a county has a statistically significant and U-shaped relationship with bankruptcy filings, primarily due to the fact that problem gamblers who file for bankruptcy protection soon after casinos open are unable to file again for protection for another six years.

Two studies also include the impact of state lotteries on bankruptcy filings. Edmiston (2006) looks at bankruptcy filings in US counties in 2000 and finds that having nearby casinos is associated with relatively higher bankruptcy filings, while the presence of racetrack facilities or lotteries is associated with lower bankruptcy filings. Daraban and Thies (2011) analyze quarterly 
bankruptcy data from 1994 to 2007 across 90 Federal Judicial Districts. They find a significant positive relationship between gambling revenues generated by casinos and lottery products and bankruptcy filings within federal districts. They estimate that because of consumer spending on gambling at casinos and on lottery products, there is an approximate $2 \%$ increase in bankruptcy filings as the result of casinos and a moderately lower increase for lotteries.

\section{B. Bankruptcies and Lotteries}

Much of the gambling literature explains that the presence of gambling may lead to higher bankruptcy filings because of the presence of problem gamblers. For most individuals, gambling likely serves as one choice among many possible recreational activities, and there is no reason to suspect that the presence of gambling should lead to higher bankruptcy filings than should the presence of any other type of entertainment. For individuals addicted to gambling, however, there is persistence in spending on gambling activities that can potentially lead to overspending and financial difficulties. Shaffer, Hall and Vander Bilt (1999) review the estimates from studies on problem gamblers in the US and Canada and report that approximately $3.85 \%$ of the adult population have some type of a gambling problem while around $1.60 \%$ of the adult population can be considered pathological gamblers. Boardman and Perry (2007) consider this latter group to be at particular risk for bankruptcy.

With respect to lottery participation and addiction, there are mixed results. Farrell, Morgenroth and Walker (1999) find evidence of addiction among UK Lotto players; however, they conclude that lottery play is considerably less addictive than addictions formed for physical products like cigarettes. Williams and Wood (2007) estimate that problem gamblers in Ontario account for about $18 \%$ of lottery sales in Ontario, $45 \%$ of gambling expenditures in for horse 
racing, and $61 \%$ of spending on gaming machines. Thus, there is evidence of some addictive behavior related to lottery products, but it is likely less of a problem than it is for drugs or other types of gambling. Grote and Matheson (2007) also find that purchasing lottery tickets in one period typically leads to additional spending on lottery tickets in the future. However, rather than evidence of addiction, the authors propose that this result is primarily generated by winners of past lotteries "reinvesting" a portion of their winnings in new lottery tickets rather than overspending on lottery tickets that can potentially lead to bankruptcy. Finally, Guryan and Kearney (2010) find that the announcement of a lottery winner in Texas Lotto can lead to additional persistent purchases of lottery tickets after 6 months and up to 18 months after the announcement. This measurement of continued persistent consumption due to a short-term event is a common method for testing for addictive behavior because "past consumption of $g$ influences current consumption of $g$ by increasing the marginal utility of current consumption."

A second important reason for considering whether state lotteries contribute to bankruptcy filings is that there is considerable evidence that lottery spending is highly regressive. In other words, individuals with lower income tend to spend a greater percentage of their income on lottery products than individuals with higher income. This finding was first identified early in the literature by Suits (1977) and Clotfelter (1979). My recently, Blalock, Just and Simon (2007) show that demand for lottery tickets is positively impacted by increases in the poverty rate. The regressive nature of lottery purchases also seems to vary depending on the lottery product. Instant game and scratch card purchases tend to be relatively more regressive in nature while ticket purchases for large jackpot online lotto games tend to be less so, particularly as the jackpots on these games rise to high levels (Mikesell, 1989). Furthermore, Garrett and Coughlin (2009) find that instant games tend to become even more regressive as these products are offered 
over longer periods of time. While the regressive nature of lottery products, on its own, is not enough to conclude that relatively lower income individuals will continue to purchase tickets until they go into bankruptcy, it does raise the question, especially when combined with possible addiction, as to whether additional spending by more financially at-risk buyers could lead to eventual bankruptcy.

It is important to note that in recent years the issue of problem gambling has received increasing attention from health professionals, the government and social service organizations, and the gaming industry itself. Pathological gaming was first officially classified as a mental health disorder only as recently as 1980 when it was first included in the Diagnostic and Statistical Manual of Mental Disorders (DSM-III) published by the American Psychiatric Association, and the 1994 update (DSM-IV) significantly expanded recommendations for the diagnosis and treatment of problem gambling. In 1996, the federal government passed the National Gambling Impact Study Commission Act which provided funding to study problem gambling. At the same time, private non-profit organizations began to form to study and treat gambling addition such as the National Center for Responsible Gaming, formed in 1996. Finally, individual states increasingly began to provide funding for the treatment of problem gambling. While fewer than 10 states offered assistance in the treatment of gambling disorders in 1980, by the early 2000s nearly every state offered some type of government aid or public-private partnership to combat problem gaming. Given the rise in public awareness of the problem and the increasingly widespread availability of treatment options, it is perhaps reasonable to believe that the potential negative consequences of easier access to gambling, such as increased bankruptcy rates, may be lessened due to proactive steps to intervene in cases of problem gambling. 


\section{Model and Methodology}

In order to test for the effect of lottery presence on bankruptcy filings, it is important to control for other variables that may also have an impact on the decision to file for bankruptcy. Other studies typically include both economic and demographic variables to explain the differences in bankruptcy filings over time in different geographic areas. This study will use annual data from 1983 to 2010 at the state level in order to test for the effect of the presence of lotteries and casinos on bankruptcy filings. This is a longer time period than most studies to date, and state-level data is most appropriate when studying the impact of lotteries, which are made available to residents throughout a state. The extended time period alone can make a significant difference in the results. Daraban and Thies (2011), for example, only include data back to 1994 by which time 37 states already had lotteries in operation, and nine states had casinos. Thus, by 1994, much of the lottery growth, in particular, had already occurred in the US, and the primary impact of lottery growth on bankruptcy filings would not be measured.

The other significant difference from the literature to date is performing regression analysis on two different types of bankruptcy filings: both business and personal (non-business). The rationale for testing the impact on both types of bankruptcy filings has to do with the expected impact of gambling participation on business versus non-business filings. The literature to date has focused on personal bankruptcy filings because the hypothesis is that personal participation in gambling puts individuals at more financial risk because of the possibility of problem gambling, which will lead to more personal bankruptcy filings. However, it could also be that a rise in casino gambling and lottery participation also causes more spending of personal income on these types of activities as opposed to spending on other entertainment options 
causing more competition and the potential failure of private non-casino businesses in states. Additionally, if personal bankruptcies are increasing due to gambling participation, this could also have an impact on the amount of personal spending by households and, therefore, sales by businesses. It is hypothesized, however, that the presence of casino gambling and lotteries should have a relatively greater impact on personal bankruptcy filings than on business filings because of the direct impact on personal income versus the more indirect impact on businesses. This proposition can be tested by performing regression analysis on each type of bankruptcy filing.

The models to be tested are

Change in PersonalBF $F_{i t}=b_{0}+b_{1}$ Unemployment $_{i t}+b_{2}$ Poverty $_{i t}+b_{3}$ Income Change $_{i t}+$

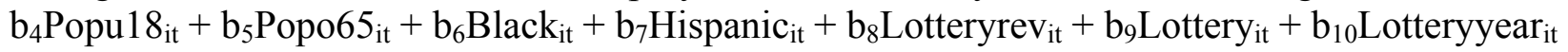
$+\mathrm{b}_{11}$ Casino $_{\text {it }}+\mathrm{b}_{12}$ Casinoyear $_{i t}+\alpha_{\mathrm{i}}+\mathrm{T}_{\mathrm{t}}+\varepsilon_{\mathrm{it}}$

Change in BusinessBF $F_{i t}=b_{0}+b_{1}$ Unemployment $_{i t}+b_{2}$ Poverty $_{i t}+b_{3}$ Income Change $_{i t}+$

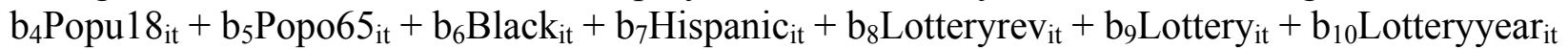
$+\mathrm{b}_{11}$ Casino $_{\text {it }}+\mathrm{b}_{12}$ Casinoyear $_{i t}+\alpha_{\mathrm{i}}+\mathrm{T}_{\mathrm{t}}+\varepsilon_{\mathrm{it}}$

where for state $\mathrm{i}$ and year $\mathrm{t}$, Change in PersonalBF $\mathrm{F}_{\text {it }}$ is the percentage change in personal (nonbusiness) bankruptcy filings, Change in BusinessBF $F_{i t}$ is the percentage change in business bankruptcy filings, Unemployment ${ }_{i t}$ is the unemployment rate, Poverty $y_{i t}$ is the poverty rate, Income Change $\mathrm{it}_{\mathrm{it}}$ is the change in real per capita state income, Popu $18_{\text {it }}$ is percent of population under 18, Popo65 $_{\text {it }}$ is percent of population over 65, Black $_{\text {it }}$ is percent of black population, Hisp $p_{\text {it }}$ is percent of Hispanic population, Lotteryrev it $_{\text {it }}$ per capita lottery revenue, Lottery it is a dummy variable equal to 1 if a state $\mathrm{i}$ has a lottery at time $\mathrm{t}$, Lotteryyear ${ }_{i t}$ is the number of years a lottery has existed in state $\mathrm{i}$ at time $\mathrm{t}, \mathrm{Casino}_{\mathrm{it}}$ is a dummy variable equal to 1 if a state $\mathrm{i}$ has a casino in operation at time $t$, Casinoyear $r_{i t}$ is the number of years a casino has been operating in state $i$ at time $t$ (including both commercial and Indian casinos), $\alpha_{i}$ are state fixed effects, $T_{t}$ are a series of dummy variables for each year t or time effects, and $\varepsilon_{\mathrm{it}}$ is the error term. 
The model is tested using panel estimation techniques in order to allow for a fixed effects approach across states to account for possible variation in the change in bankruptcy filings geographically and also includes time dummy variables to measure the how the bankruptcy filings change over time, ceteris paribus. Bankruptcy data is provided by Table F of the US Bankruptcy Courts, economic and demographic data is provided by the Bureau of Labor Statistics and the Census Bureau, lottery revenue data is provided by the Statistical Abstract of the United States and the DC Lottery and Charitable Games Control Board Annual Reports (various years), lottery start dates are provided by state lottery association websites and casino start dates are provided by the American Gaming Association, websites of gaming commissions in various states, as well as the National Congress of American Indians Gaming Compacts (ncai.org). Although some Indian casinos were in operation prior to the 1988 Indian Gaming Regulatory Act, obtaining accurate start dates and operation dates for casinos prior to this time is difficult and not precise, so the current analysis only includes start dates for states with commercial casinos and states with Class III Indian casinos that are subject to agreements made between the Indian casinos and the states in which they operate post-1988.

Rather than running a panel regression using data across the entire 1983 to 2010 time period, the time period is divided in order to account for both changes in gambling markets during this time period as well as the expansion of services to address problem gambling. Much of the growth in state lottery adoptions occurred prior to the 1990s, while much of the growth in casinos occurred in the early 1990s. Prior to 1990, 33 states had already adopted state lotteries, while only five states allowed casino operations (with the exception of some Indian casinos that are not included in the analysis). By 1995, only four additional states added lotteries while 19 more states allowed casinos to operate, the biggest 5-year period of growth in states legalizing 
casino operations. By 1995, 37 of the 44 lottery states had begun their lotteries and 24 of the 31 states with casinos had allowed operations to begin. Additionally, by the 1990s, there was already much more known about the issue of problem gambling and state programs to help problem gamblers. Taking all of these factors into account, it seems very likely that the impact of lotteries and casinos on bankruptcy filings should be very different prior to the mid-1990s compared to after this period. The 1983 to 2010 time period is, therefore, split at the year 1995 so panel regression techniques are used on the period 1983 to 1994 and 1995 to 2010 for that reason. One other concern regarding the time period analyzed is the passage of the Bankruptcy Reform Act of 2005. As this Act made it more difficult for households to file for personal bankruptcy, there should be an increase in personal bankruptcy filings immediately prior to 2005 in anticipation of the Act and fewer filings after this date. In order to exclude any "dampening" in the change in bankruptcy filings after 2005, the post-1995 time period is also limited in a separate panel regression to end in 2004.

The dependent variables in the models are percent changes in bankruptcy filings as opposed to bankruptcy filing rates, a more common dependent variable used in the rest of the literature. The rationale for not using bankruptcy filing rates when using dummy variables for the presence of casinos and lotteries is that there have only been additions to the number of states offering casinos and lotteries over the time period studied. No states have completely dropped casinos and/or lotteries once they are first offered. Since bankruptcy filings have also typically increased over this same time period (with the exception of the period immediately following the passage of the Bankruptcy Reform Act of 2005), any measured statistical relationship between the presence of gambling and the number of bankruptcies or bankruptcy filing rates is likely to be positive leading to the distinct possibility of spurious correlation unless one is extremely 
careful about purging time trends from the dependent variable (Baumann and Matheson, 2012).

This trend between personal bankruptcy filings and the increasing presence of casinos and lotteries in states over time is presented in Figure 1.

Using the percentage change in bankruptcy filings is an effective method of removing the underlying trends from the dependent variable as there is no expectation that rate of increase of bankruptcy filings will grow by each year avoiding the problem created by using dummy variables that "turn on" but never "turn off" to measure the presence of gambling.

The predicted effects of the economic and demographic variables follow very closely with the predicted and measured effects from the bankruptcy and gambling literature to date, and the current model follows particularly closely with the models of Goss, Morse and Deskins (2009) and Daraban and Thies (2011) although the current data is at the state level and over a longer period of time. The unemployment rate, poverty rate and change in per capita income are included to measure general economic conditions within states over time. There is expected to be a direct relationship between state unemployment rates and the change in state bankruptcy filings, both business and personal, as higher unemployment rates increase the financial risks to both households and businesses. Similarly, poverty rates are also expected to have a direct relationship with the change in state bankruptcy filing rates as higher poverty rates are associated with states that have more families struggling economically. Change in per capita income is expected to have an inverse relationship with the change in state bankruptcy filings as states with increasing real per capita income should be associated with declining state bankruptcy filings. The three economic variables are likely correlated with one another and may result in multicollinearity in the regression models; however, each of the three variables provides different information about the current or changing state economy and may be relatively more or less 
important when considering the impact on changes in business versus personal bankruptcy filings.

Regarding demographics, states with relatively higher percentages of their population either under 18 or over 65 are expected to have fewer bankruptcy filings, either because individuals in this age group are not of a legal age to file for bankruptcy (under 18) or are at an age where they are more likely to have acquired significant assets to avoid bankruptcy (over 65). The final demographics regard race with higher percentages of black and Hispanic populations expected to have higher bankruptcy filings in states. These demographic variables are expected to affect personal bankruptcy filings relatively more than business filings although, similar to the presence of gambling, one could argue that these demographics can also affect household consumption patterns across states which could potentially affect business bankruptcy filings as well, albeit at a lower expected level.

The variables measuring the presence of casinos also follows very closely with Goss, Morse and Deskins (2009) although they use a quadratic form to account for number of years that a casino is in operation in a state to account for differences in effects on bankruptcies when casinos first open as well as when they are open for longer periods of time. The current model uses a linear estimation of that effect along with a linear estimation of the effect from lotteries, to test for the additional effect on bankruptcies as casino or lottery operations attract more in-state customers and provide additional time for gamblers in either activity to become addicted to spending on these activities.

Lottery revenues per capita are included to determine if the increased spending on lotteries within a state account for additional bankruptcy filings within a state. Daraban and Thies (2011) include this variable in their study along with a similar variable for casino 
spending. However, due to the uncertainty of the data provided by Indian casinos, which do not have to meet the same financial reporting requirements as commercial casinos, this variable is not included in the current model. The inclusion of dummy variables for each year to estimate changes in bankruptcy rates over time also follows the methodology of Daraban and Thies (2011).

\section{Results}

Table 1 provides the statistical summaries for the variables across the entire time period, 1983 to 2010 , while Table 2 presents summary statistics for the two divided periods, 1983 to 1994 and 1995 to 2010. As revealed by the summary statistics, the average personal bankruptcy filing rate is higher than the average business bankruptcy filing rate for the time period studied (3.381 percent versus 0.224 percent), and personal bankruptcy filings also have a higher average rate of change in filings from 1983 to 2010, over double that of the annual average percent change in business filings ( 8.582 percent per year versus 3.258 percent per year). When looking at these rates in the divided time periods, the personal bankruptcy filing rate is also relatively higher after 1995 (compared to earlier), but it grows at a lower rate. The opposite is true for business bankruptcy filings. While most of the economic and demographic data appear to be similar across the two time periods, the percent Hispanic does appear to increase post-1995 and real per capita lottery revenues are certainly higher post-1995.

The results of the estimated panel models, over the three different time periods examined, are presented in Table 3 . Note that state fixed effects and yearly dummy variables are included each model; however, the coefficients on the state and year variables are excluded for brevity. 
In the 1983 to 1994 estimated models, there are three variables that have statistical significance in explaining percentage changes in bankruptcy filings for both businesses and nonbusinesses over the time period: the unemployment rate and the two age demographics, the percentage of the population under 18 years of age and percentage of population over 65 , all having the predicted relationship with changes in bankruptcy filings. Additional variables are also significant for explaining changes in personal bankruptcy filings, but not business filings, over this same time period. Both poverty rate and change in real per capita income are significant although the poverty rate is of the wrong sign, likely due to multi-collinearity. The percent of population that is black is also significant and of the correct sign for changes in personal bankruptcies, while the percent of population that is Hispanic is not significant. Most interesting, however, is that both the number of years that a state has had a lottery and the number of years that a state has allowed legal casino operations are also significant contributors to changes in personal bankruptcy filings, but not business filings. The impact of casinos is slightly larger than lotteries, but the coefficients are very close in value, 1.329 for years of lottery operation and 1.728 for years of casino operations. Overall, this model does the best of all models considered in predicting changes in bankruptcy filings as can be seen from the F-statistic, as well.

For the post-1995 time period, the results are significantly different with several interesting results worth discussing. The only variables useful in explaining changes in personal bankruptcy filings post-1995 are the unemployment rate for the period 1995 to 2004 and the percent of population that is Hispanic from 1995 to 2010 . It may well be that the multicollinearity problem among unemployment rate, poverty rate and change in real per capita income is a bigger problem post-1995 than it was prior to 1995. In fact, if the poverty rate and change in income were dropped from the post-1995 models, the unemployment rate would be 
significant in both. Regarding the Hispanic population post-1995, one can see by the summary statistics for the two periods in Table 2 that percent Hispanic is much higher on average after 1995: $8.430 \%$ of population post-1995 and 5.093\% pre-1995. Most likely, the significance of the Hispanic variable in the post-1995 period reflects the large increase in bankruptcies in the southern states in the wake of the housing bust of the mid to late 2000s. While this demographic change does appear to have contributed to greater increases in personal bankruptcy filings post1995, the effect goes away if one does not include the years following the new bankruptcy law. For changes in business bankruptcy filings in the post-1995 periods examined, the poverty rate becomes the most significant economic explanatory variable as opposed to the unemployment rate. The change in real per capita income is also significant and of the correct sign for the 1995 to 2010 period. While one must be careful about multi-collinearity in interpreting these results, it does appear that the poverty rate, which is never a significant predictor (of the correct sign) for changes in personal bankruptcy filings in any of the time periods examined, is significant for changes in business bankruptcy filings post-1995. One possible explanation for this may be that when poverty levels are high, businesses in those states experience not only lower sales for a short period of time, as they might if unemployment is high, but for more extended periods if poverty is a longer term problem than unemployment. Higher poverty rates may also contribute more negatively to community and regional economic problems, in general, than high unemployment, thus affecting the business community more adversely in those areas.

Certainly the most interesting result from all of the models taken together is that the increasing presence of casinos and lotteries only has a significant impact on personal bankruptcy filings prior to 1995 . While these results run counter to the findings in the more recent empirical 
literature, they can be explained by two compelling arguments. The first is that gambling activities should have a relatively larger impact on personal spending when they are first introduced and that this effect gradually declines over time. This is referred to as "lottery fatigue" in the lottery literature and has been shown to exist empirically by measuring the relatively declining impact of advertised lotteries on lottery sales (Matheson and Grote, 2005). The second compelling argument is related to problem gambling. As mentioned previously the percentage of problem gamblers who would likely over-spend on casinos or lotteries enough to run the risk of bankruptcy is a relatively low number. Over time, the ability to identify problem gambling as well as the ability to offer counseling and other efforts to combat the problem have also improved. So even if the existence of gambling over longer time periods adds to the potential for more problem gambling and addiction to form, this may be offset by more social awareness of the problem in later years, which mitigates the effects of gambling behavior on economic outcomes, like bankruptcy filings.

\section{Conclusions}

Recent literature suggests that the growth in gambling activities in the United States, and particularly the growth in casino gambling, contributes to the growth in personal bankruptcy filings. This is in contrast to the results of some earlier studies on gambling and bankruptcies. Using data at the state level from 1983 to 2010 , divided into three different time periods, the current study finds evidence that while the presence of lotteries and casino gambling contributed significantly to the annual percent changes in personal bankruptcy filings prior to 1995 , this effect is not present post-1995, possibly because of increasing efforts to identify problem gambling as the presence of gambling spreads across the state. The most persistent economic 
variables in measuring changes in bankruptcy filings are the unemployment rate, which is positive and significant in three of the models, for both business and non-business bankruptcies, and the poverty rate for business bankruptcies post-1995. Race demographics appear to affect changes in personal, but not business, bankruptcy filings, with the percentage of population that is black having a positive and significant effect pre-1995 and the percentage of population that is Hispanic having a positive and significant effect post-1995. The results of these models differ from previous contributions primarily because of the time period studied (which is longer) and the use of changes in both business and non-business bankruptcy filings at state levels as a measure of bankruptcy rather than non-business bankruptcy filing rates at county or district levels within states.

The results indicate that further research is necessary to examine the complex relationship between the presence of gambling and bankruptcy filings. While compelling arguments can certainly be made about increasing gambling addiction as casinos and lotteries are allowed by more states, one can also argue that personal spending on these types of activities may be relatively higher when gaming is first offered by states, but declines over time, and that there is more awareness of problem gambling, resulting in more efforts to mitigate the social and economic impacts of problem gambling over time. 


\section{References}

Barron, John M., Michael E. Staten and Stephanie M. Wilshusen. 2002. "The Impact of Casino Gambling on Personal Bankruptcy Filing Rates," Contemporary Economic Policy 20: 440-455.

Baumann, Robert and Victor A. Matheson. 2012. "Estimating economic impact using ex post econometric analysis: Cautionary tales," in Sports and Econometrics, Plácido Rodríguez, Stefan Kesenne and Jaume García, eds., (London: Edward Elgar), forthcoming.

Blalock, Garrick, David R. Just and Daniel H. Simon. 2007. "Hitting the Jackpot or Hitting the Skid: Entertainment, Poverty, and the Demand for State Lotteries," American Journal of Economics and Sociology 66 (3): 545-570.

Boardman, Barry and John J. Perry. 2007. “Access to Gambling and Declaring Personal Bankruptcy," The Journal of Socio-Economics 36: 789-801.

Clotfelter, Charles T. 1979. “On the Regressivity of State-Operated Numbers Games,” National Tax Journal 32 (4): 543-548.

Daraban, Bogdan and Clifford F. Thies. 2011. "Estimating the Effects of Casinos and of Lotteries on Bankruptcy: A Panel Data Set Approach,” Journal of Gambling Studies 27: $145-154$.

De la Vina, Lynda and David Bernstein. 2002. "The Impact of Gambling on Personal Bankruptcy Rates,” Journal of Socio-Economics 31: 503-509.

Emiston, Kelly D. 2006. “A New Perspective on Rising Nonbusiness Bankruptcy Filing Rates: Analyzing the Regional Factors," Federal Reserve Bank of Kansas City Economic Review Q2: 55-83. 
Farrell, Lisa, Edgar Morgenroth and Ian Walker. 1999. “A Time Series Analysis of UK Lottery Sales: Long and Short Run Price Elasticities,” Oxford Bulletin of Economics and Statistics 61 (4): 513-526.

Garrett, Thomas A. and Cletus C. Coughlin. 2009. "Inter-Temporal Differences in the Income Elasticity of Demand for Lottery Tickets," National Tax Journal 62 (1): 77-99.

Goss, Ernie, Edward A. Morse and John Deskins. 2009. "Have Casinos Contributed to Rising Bankruptcy Rates?” International Advances in Economic Research 15: 456-469.

Grote, Kent R. and Victor A. Matheson. 2007. "Examining the Halo Effect in Lotto Games," Applied Economic Letters 14 (4-6): 307-310.

Guryan, Jonathan and Melissa S. Kearney. 2010. “Is Lottery Gambling Addictive?” American Economic Journal: Economic Policy 2 (3): 90-110.

Matheson, Victor A. and Kent R. Grote. 2005. "Rationality and Efficiency in Lotto Games," in Information Efficiency in Financial and Betting Markets, Leighton Vaughn Williams, ed. (London: Cambridge University Press), 313-329.

Mikesell, John. 1989. “A Note on the Changing Incidence of State Lottery Finance,” Social Science Quarterly 70 (2): 513-521.

National Opinion Research Center (NORC). 1999. "Gambling Impact and Behavior Study: Report to the National Gambling Impact Study Commision,” April 1999.

Nichols, Mark W., B. Grant Stitt and David Giacopassi. 2000. "Casino Gambling and Bankruptcy in New United States Casino Jurisdictions," Journal of Socio-Economics 29: 247-261. 
Shaffer, Howard J., Matthew N. Hall and Joni Vander Bilt. 1999. "Estimating the Prevalence of Disordered Gambling Behavior in the United States and Canada: A Research Synthesis," American Journal of Public Health 89 (9): 1369-1376.

Suits, Daniel B. 1977. "Gambling Taxes: Regressivity and Revenue Potential," National Tax Journal 30 (1): 19-35.

Thalheimer, Richard and Mukhtar M. Ali. 2004. "The Relationship of Pari-Mutuel Wagering and Casino Gaming to Personal Bankruptcy," Contemporary Economic Policy 22 (3): $420-432$.

US Treasury. 1999. “A Study of the Interaction of Gambling and Bankruptcy,” July, 1999. Williams, Robert J. and Robert T. Wood. 2007. "The Proportion of Ontario Gambling Revenue Derived from Problem Gamblers," Canadian Public Policy 33 (3): 367-387. 
Figure 1

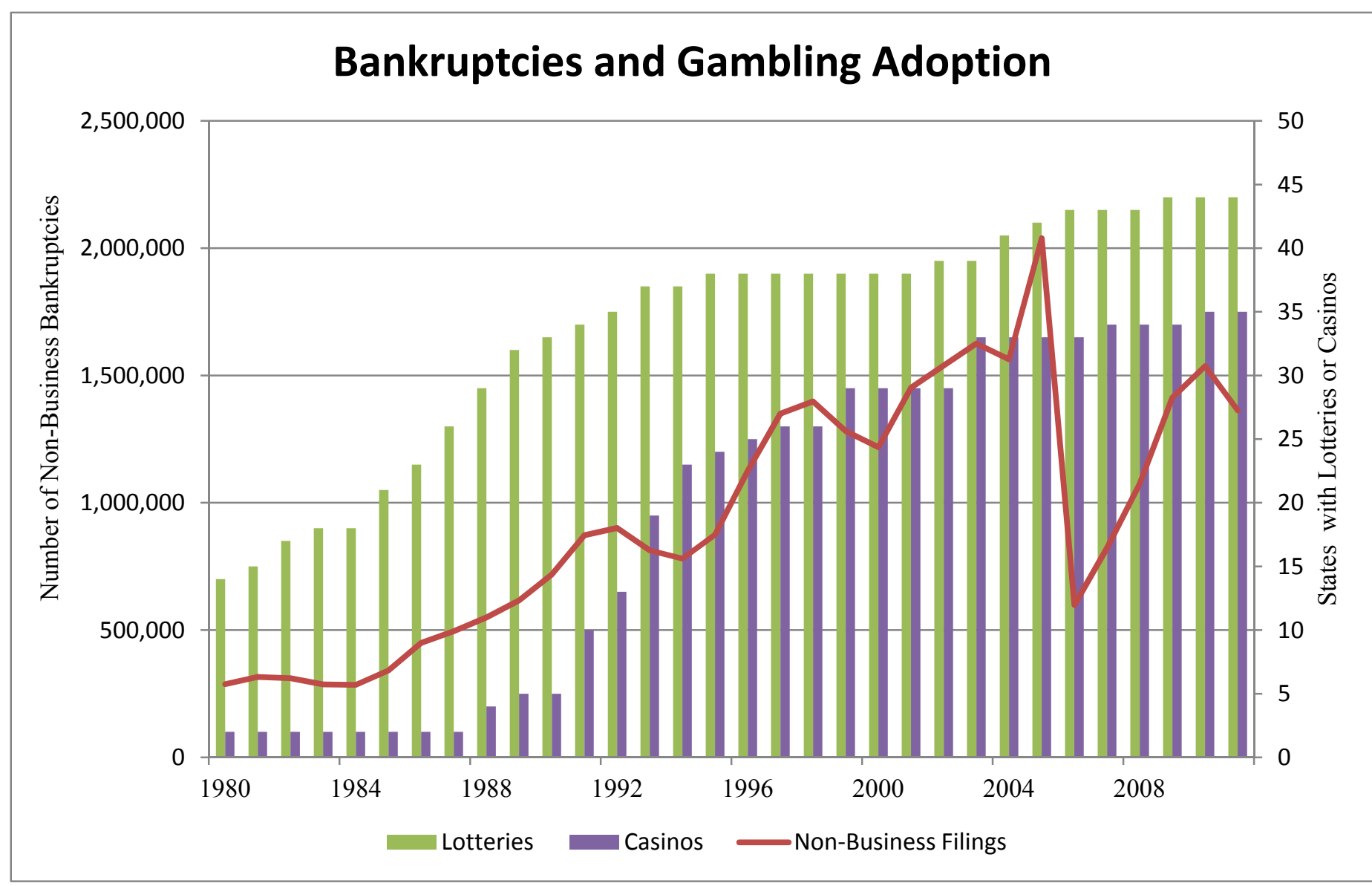


Table 1: Summary Statistics

$\underline{1983-2010}$

Variable:

Business Bankruptcy Filing Rate

$\%$ Change in Business Filings

Personal Bankruptcy Filing Rate

$\%$ Change in Personal Filings

Unemployment Rate

Poverty Rate

$\%$ Change in Real Per Capita Income

$\%$ Under 18

$\%$ Over 65

$\%$ Black

$\%$ Hispanic

Real Per Capita Lottery Revenue $\underline{\text { Std. }}$

Mean $\quad \underline{\text { Dev. }} \quad \underline{\text { Min }} \quad \underline{\text { Max }}$

$\begin{array}{rrrr}0.224 & 0.206 & 0.027 & 3.269\end{array}$

$\begin{array}{llll}3.258 & 36.142 & -85.709 & 429.537\end{array}$

$\begin{array}{rrrr}3.381 & 1.967 & 0.258 & 11.147\end{array}$

$\begin{array}{llll}8.582 & 27.049 & -82.078 & 649.276\end{array}$

$\begin{array}{llll}6.019 & 2.165 & 2.300 & 17.400\end{array}$

$\begin{array}{rrrr}13.082 & 3.923 & 2.900 & 27.200\end{array}$

$\begin{array}{llll}1.465 & 2.336 & -11.335 & 9.435\end{array}$

$\begin{array}{llll}25.788 & 2.541 & 16.711 & 37.494\end{array}$

$\begin{array}{llll}12.32 & 2.007 & 2.866 & 18.209\end{array}$

$\begin{array}{llll}10.853 & 11.735 & 0.224 & 69.151\end{array}$

$\begin{array}{llll}6.661 & 8.286 & 0.465 & 44.96\end{array}$

$\begin{array}{llll}116.656 & 145.147 & 0 & 1,238.82\end{array}$ 
Table 2: Summary Statistics for Divided Data Set

\begin{tabular}{lrrrrr} 
& \multicolumn{2}{c}{ Pre-1995 } & & \multicolumn{2}{c}{ Post-1995 } \\
Variable: & $\underline{\text { Mean }}$ & $\underline{\text { Std. Dev. }}$ & & Mean & $\underline{\text { Std. Dev. }}$ \\
Business Bankruptcy Filing Rate & 0.306 & 0.201 & & 0.163 & 0.188 \\
\% Change in Business Filings & 1.365 & 32.618 & & 4.483 & 38.219 \\
Personal Bankruptcy Filing Rate & 2.153 & 1.328 & & 4.301 & 1.863 \\
\% Change in Personal Filings & 11.118 & 19.514 & 6.941 & 30.862 \\
Unemployment Rate & 6.726 & 2.192 & 5.437 & 1.961 \\
Poverty Rate & 13.868 & 4.297 & 12.434 & 3.456 \\
\% Change in Real Per Capita Income & 1.582 & 2.300 & 1.376 & 2.361 \\
\% Under 18 & 26.710 & 2.669 & 24.769 & 2.124 \\
\% Over 65 & 12.019 & 2.178 & 12.698 & 1.789 \\
\% Black & 10.511 & 11.979 & 11.156 & 11.425 \\
\% Hispanic & 5.093 & 7.178 & 8.430 & 9.107 \\
Real Per Capita Lottery Revenue & 67.247 & 92.727 & 157.670 & 166.518
\end{tabular}


Table 3: Panel Regression Results

\% Change in Personal

Bankruptcy Filings
$\%$ Change in Business Bankruptcy Filings

\begin{tabular}{|c|c|c|c|c|c|c|}
\hline \multirow{3}{*}{$\begin{array}{l}\text { Time Period: } \\
\text { Unemployment Rate }\end{array}$} & '83-'94 & $95-' 10$ & '95-`04 & '83-'94 & '95-'10 & '95-04 \\
\hline & $6.059 * * *$ & 1.756 & $5.966^{* *}$ & $5.898^{* * *}$ & 0.474 & -4.820 \\
\hline & $(.774)$ & (1.197) & $(2.912)$ & $(1.882)$ & (1.683) & $(3.551)$ \\
\hline \multirow[t]{2}{*}{ Poverty Rate } & $-.633^{*}$ & 0.394 & 0.427 & 0.223 & $3.319 * * *$ & $4.171^{* * *}$ \\
\hline & $(.368)$ & $(.676)$ & $(1.051)$ & $(.894)$ & $(.950)$ & $(1.281)$ \\
\hline \multirow[t]{2}{*}{ Income Change } & $-1.193 * * *$ & -0.496 & 0.964 & -0.829 & $-1.452^{*}$ & -1.772 \\
\hline & $(.400)$ & $(.584)$ & $(1.026)$ & $(.972)$ & $(.821)$ & $(1.251)$ \\
\hline \multirow[t]{2}{*}{$\%$ Under 18} & $-11.197 * * *$ & -1.706 & 4.194 & $-18.558 * * *$ & -0.286 & -6.027 \\
\hline & (1.903) & $(2.355)$ & $(4.537)$ & $(4.626)$ & $(3.312)$ & $(5.531)$ \\
\hline \multirow{2}{*}{$\%$ Over 65} & $-10.152 * * *$ & 0.366 & 5.275 & $-12.600 *$ & -3.037 & -10.778 \\
\hline & $(2.686)$ & $(3.267)$ & $(7.851)$ & $(6.529)$ & (4.594) & $(9.571)$ \\
\hline \multirow[t]{2}{*}{$\%$ Black } & $5.668 * * *$ & -0.191 & 3.074 & 6.998 & $-5.891 * *$ & -6.618 \\
\hline & $(2.068)$ & $(1.820)$ & $(5.820)$ & $(5.027)$ & $(2.559)$ & (7.095) \\
\hline \multirow[t]{2}{*}{ \% Hispanic } & -0.642 & $2.564 * *$ & 1.2 & 4.539 & 1.420 & 2.214 \\
\hline & (1.620) & $(1.054)$ & (1.946) & (3.938) & (1.482) & (2.372) \\
\hline \multirow{2}{*}{ Lottery Revenue } & -0.001 & -0.006 & -0.010 & -0.026 & 0.011 & 0.017 \\
\hline & $(.018)$ & $(.016)$ & $(.028)$ & $(.044)$ & $(.022)$ & $(.034)$ \\
\hline \multirow[t]{2}{*}{ Lottery } & -2.317 & -3.793 & 3.734 & -4.363 & -7.188 & 1.169 \\
\hline & $(2.632)$ & $(5.865)$ & $(14.714)$ & $(6.397)$ & $(8.248)$ & $(17.938)$ \\
\hline \multirow[t]{2}{*}{ Lottery Years } & $1.329 * * *$ & -0.136 & -0.073 & 1.694 & -0.729 & 0.215 \\
\hline & $(.452)$ & $(.512)$ & $(1.179)$ & $(1.010)$ & $(.719)$ & $(1.438)$ \\
\hline \multirow[t]{2}{*}{ Casino } & -1.673 & 0.127 & 1.635 & -4.545 & 2.511 & -0.410 \\
\hline & (2.739) & (5.613) & (9.956) & (6.658) & (7.893) & (12.138) \\
\hline \multirow[t]{2}{*}{ Casino Years } & $1.728 * * *$ & 0.577 & 1.535 & 2.155 & 0.218 & 0.097 \\
\hline & $(.770)$ & $(.414)$ & $(1.023)$ & $(1.872)$ & $(.582)$ & $(1.248)$ \\
\hline State Fixed Effects & Yes & Yes & Yes & Yes & Yes & Yes \\
\hline Time Fixed Effects & Yes & Yes & Yes & Yes & Yes & Yes \\
\hline F-statistic & $2.88^{* * *}$ & 0.86 & 0.78 & 1.03 & $1.36^{*}$ & 0.83 \\
\hline Prob $>$ F & 0.000 & 0.7364 & 0.8640 & 0.4237 & 0.0512 & 0.7968 \\
\hline
\end{tabular}

Standard errors of the coefficients are indicated in parentheses below each coefficient value. ***significant at $1 \%$ level; ** significant at $5 \%$ level; * significant at $10 \%$ level 